\title{
Study Subject Computed Tomography Image
}

National Cancer Institute

\section{Source}

National Cancer Institute. Study Subject Computed Tomography Image. NCI Thesaurus.

Code C115481.

A computed tomography image of a study participant for use in the clinical trial. 